Supporting Information

\title{
Probing the Lewis Acid Sites and CO Catalytic Oxidation Activity of the Porous Metal-Organic Polymer $[\mathrm{Cu}(\mathrm{mipt})](\mathrm{MIPT}=$ 5-methylisophthalate)
}

\author{
Ru-Qiang Zou, ${ }^{\text {a,b }}$ Horoaki Sakurai, ${ }^{a}$ Song Han, ${ }^{a}$ Rui-Qin Zhong, ${ }^{\text {a,b }}$ and Qiang Xu ${ }^{\text {a,b, } *}$ \\ ${ }^{a}$ National Institute of Advanced Industrial Science and Technology (AIST), Ikeda, Osaka 563-8577, \\ and ${ }^{b}$ Graduate School of Science and Technology, Kobe University, Nada Ku, Kobe, Hyogo \\ 657-8501, Japan; E-mail: q.xu@aist.go.jp
}




\section{Experimental Details}

Synthesis of $\left[\mathbf{C u}(\mathbf{m i p t})\left(\mathrm{H}_{2} \mathrm{O}\right)\right]\left(\mathbf{H}_{2} \mathbf{O}\right)_{2}(\mathbf{1})$. A solution of $\mathrm{Cu}\left(\mathrm{NO}_{3}\right)_{2} \cdot 2.5 \mathrm{H}_{2} \mathrm{O}(697 \mathrm{mg}, 3 \mathrm{mmol})$ in $20 \mathrm{~mL}$ of water was added to a solution of 5-methylisophthalic acid (540 mg, $3 \mathrm{mmol})$ in $20 \mathrm{~mL}$ water and the mixture was heated to $140{ }^{\circ} \mathrm{C}$ inside a $100 \mathrm{~mL}$ Tefloncapped scintillation. X-ray quality crystals were collected from the walls of the vial after 4 day. The crystals were rinsed with successive 20- $\mathrm{mL}_{2} \mathrm{O}$ and $\mathrm{C}_{2} \mathrm{H}_{5} \mathrm{OH}$, and dried in air to afford $577 \mathrm{mg}(65 \%)$ of $\mathbf{1}$ as a blue crystalline material. Anal. calcd. for $\mathbf{1 ~ C u C}_{9} \mathrm{H}_{12} \mathrm{O}_{7}$ : C, 36.55; H, 4.09. Found: C, 36.05; H, 3.79.

Elemental analysis results of materials for both after removal of guest solvent molecules (1a) and after catalytic reaction (1b). Anal. calcd. for $1 \mathbf{a} \mathrm{CuC}_{9} \mathrm{H}_{6} \mathrm{O}_{4}: \mathrm{C}, 44.73 ; \mathrm{H}, 2.50$. Found: $\mathrm{C}, 44.98 ; \mathrm{H}$, 2.06. Anal. calcd. for $\mathbf{1 b} \mathrm{CuC}_{9} \mathrm{H}_{6} \mathrm{O}_{4}: \mathrm{C}, 44.73 ; \mathrm{H}, 2.50$. Found: $\mathrm{C}, 45.23 ; \mathrm{H}, 2.15$.

X-ray Structure Determinations. X-ray single-crystal diffraction data for the two title complexes were collected on a Bruker Smart 1000 CCD diffractometer at 293 (2) K with Mo-K $\alpha$ radiation $(\lambda=$ $0.71073 \AA$ ) by $\omega$ scan mode, respectively. The program SAINT was used for integration of the diffraction profiles. All the structures were solved by direct methods using the SHELXS program and refined by full-matrix least-squares methods with SHELXL. Metal atoms in each complex were located from the $E$-maps and other non-hydrogen atoms were located in successive difference Fourier syntheses and refined with anisotropic thermal parameters on $F^{2}$. The hydrogen atoms of the ligand were generated theoretically onto the specific atoms and refined isotropically with fixed thermal factors.

IR Measurements. The IR spectra were recorded on a Bruker ISS/v6 apparatus at a spectral resolution of $2 \mathrm{~cm}^{-1}$ accumulating 128 scans. The dry sample powder is mixed by $\gamma-\mathrm{Al}_{2} \mathrm{O}_{3}$ (heated at $600{ }^{\circ} \mathrm{C}$ for $6 \mathrm{~h}$ ) and treated directly in the purpose-made IR cell. The latter was connected to a vacuum-adsorption apparatus with a residual pressure below $10^{-3} \mathrm{~Pa}$. The cell allowed the IR measurements to be performed both at ambient temperature. Prior to the adsorption measurements, 
the samples were activated by heating for $1 \mathrm{~h}$ in air at $250{ }^{\circ} \mathrm{C}$ and $1 \mathrm{~h}$ evacuation at the same temperature within the cell system. Carbon monoxide ${ }^{12} \mathrm{CO}(99.95 \%)$ and ${ }^{13} \mathrm{CO}(>99 \%)$ were used in the preparation of the $\mathrm{CO} / \mathrm{Ar}$ mixtures. It should be noted that the dry $\gamma-\mathrm{Al}_{2} \mathrm{O}_{3}$ as well as the Ni-containing MOP (refer. 8) sample never presents a similar CO adsorption property to complex $\mathbf{1}$ at room temperature.

Catalysis Measurements. A multipurpose TPD equipment (TP-5000, Ohkura Riken Co., Ltd.) was used as a flow reactor of $\mathrm{CO}$ oxidation. Pure $\mathrm{CO}, \mathrm{O}_{2}$ and $\mathrm{He}$ were supplied through mass flow controllers and mixed with each other, and then the final reactant gas $\left(100 \mathrm{ml} \mathrm{min}{ }^{-1}\right)$ was passed through the catalyst bed $(0.3 \mathrm{~g})$. The sample was calcinated in air at $250{ }^{\circ} \mathrm{C}$ for $3 \mathrm{~h}$ before the reaction. Reaction gas was composed from $\mathrm{CO}\left(1\right.$ vol. \%), $\mathrm{O}_{2}(20$ vol. \%) and He (balance), and hourly space velocity (SV) was $20,000 \mathrm{~h}^{-1} \mathrm{ml} / \mathrm{g}$-catal. The reaction temperature was programmed between room temperature and $205^{\circ} \mathrm{C}$ and monitored by thermocouple.

Reactants and products were analyzed by using a QMS analyzer (MMC-200, ULVAC Co., Ltd.), and a FID-GC (GC-14B, Shimadzu Co., Ltd) equipped with a methanizer (MT-221, GL Science Co., Ltd.). Signals of QMS were monitored during all of the reaction, and GC analyses were carried out after stabilization of temperature at $104,132,160$ and $205^{\circ} \mathrm{C}$.

Conversion to $\mathrm{CO}_{2}$ was calculated from $\mathrm{GC}$ data $\left(\mathrm{X}_{\mathrm{GC}}\right)$ according to

$$
\mathrm{X}_{\mathrm{GC}}=\mathrm{A}_{\mathrm{CO} 2} /\left(\mathrm{A}_{\mathrm{CO}}+\mathrm{A}_{\mathrm{CO} 2}\right) \times 100(\%)
$$

where $\mathrm{A}_{\mathrm{CO}}$ and $\mathrm{A}_{\mathrm{CO} 2}$ are the peak areas of $\mathrm{CO}$ and $\mathrm{CO}_{2}$ detected by GC, respectively. Figure $7 \mathrm{~S}$ shows thus obtained $\mathrm{X}_{\mathrm{GC}}$ plotted vs. temperature and compared with data on previously reported $\mathrm{Ni}$ containing MOP. Conversion to $\mathrm{CO}_{2}$ was also calculated from QMS data ( $\left.\mathrm{X}_{\mathrm{QMS}}\right)$ according to

$$
\mathrm{X}_{\mathrm{QMS}}=\mathrm{k} \times \mathrm{S}_{44} /\left(\mathrm{k} \times \mathrm{S}_{44}+\mathrm{S}_{28}-\mathrm{S}_{28(\mathrm{CO} 2)}\right) \times 100(\%)
$$

where $\mathrm{S}_{28}$ and $\mathrm{S}_{44}$ are the intensities of QMS signals having $\mathrm{m} / \mathrm{z}$ values of $28(\mathrm{CO})$ and $44\left(\mathrm{CO}_{2}\right), \mathrm{k}$ $(=1.05)$ is the experimentally determined factor which correct the difference in molar sensitivity of CO 
and $\mathrm{CO}_{2}$, and $\mathrm{S}_{28 \text { (CO2) }}$ is the contribution of the $\mathrm{m} / \mathrm{z}=28$ fragment from the $\mathrm{CO}_{2}$. The values of $\mathrm{X}_{\mathrm{GC}}$ and $\mathrm{X}_{\mathrm{QMS}}$ are almost agreed after stabilization of temperature. Figure $8 \mathrm{~S}$ shows thus obtained $\mathrm{X}_{\mathrm{QMS}}$ plotted vs. reaction time at the fixed temperatures of 104,132 , and $160{ }^{\circ} \mathrm{C}$, which shows the stable catalytic activity.

Reaction rate $\left(\mathrm{R}, \mathrm{mol}\right.$ of $\left.\mathrm{CO}_{2}(\mathrm{~mol} \text { of } \mathrm{Cu} \cdot \mathrm{s})^{-1}\right)$ was calculated as follows:

$$
\begin{aligned}
\mathrm{R}_{\mathrm{GC}} & =\mathrm{X}_{\mathrm{GC}} \times \mathrm{F}_{\mathrm{CO}} / \mathrm{M}_{\mathrm{Cu}} \\
\mathrm{R}_{\mathrm{QMS}} & =\mathrm{X}_{\mathrm{QMS}} \times \mathrm{F}_{\mathrm{CO}} / \mathrm{M}_{\mathrm{Cu}}
\end{aligned}
$$

$\mathrm{F}_{\mathrm{CO}}\left(\mathrm{mol} \mathrm{s}^{-1}\right)$ is flow rate of $\mathrm{CO}$ in reactant gas, and $\mathrm{M}_{\mathrm{Cu}}$ is the amount of $\mathrm{Cu}(\mathrm{mol})$ in used catalyst (0.3g) calculated from the formula weight of dehydrated form $\left[\mathrm{Cu}_{2}(\mathrm{~L})_{2}\right]$. As for $\mathrm{R}_{\mathrm{QMS}}$ shown in the arrhenius plot (Fig. 2), only $\mathrm{X}_{\mathrm{QMS}}$ data smaller than $20 \%$ was used for the calculation. The figure shows $\mathrm{R}_{\mathrm{GC}}$ and $\mathrm{R}_{\mathrm{QMS}}$ are almost agreed and linear for both $\mathbf{1}$ and Ni-containing MOP.

Other Physical Measurements. Powder X-ray diffraction data was collected using $\mathrm{Cu} \mathrm{K} \alpha(\lambda=$ $1.5406 \AA$ ) radiation on a Rigaku X-ray diffractometer. Thermogravimetric analyses were carried out at a ramp rate of $5{ }^{\circ} \mathrm{C} / \mathrm{min}$ in a Helium atmosphere using Shimadzu DTG-50 instrument. Elemental analyses were performed on a Perkin-Elmer 2400 Series II analyzer. TEM images were recorded using a Hitachi H-9000NA transmission electron microscope. 


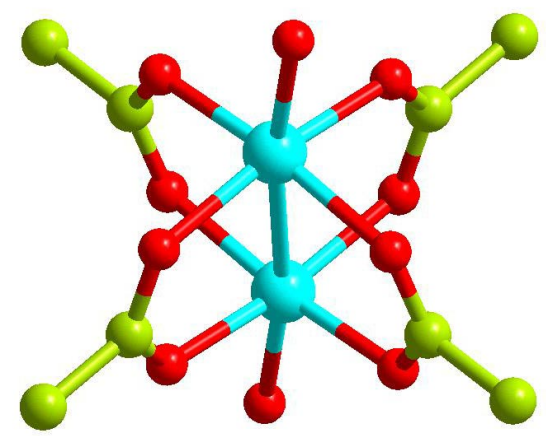

Figure S1 The Paddle-wheel $\mathrm{Cu}-\mathrm{Cu}$ cluster of $\mathbf{1}$. 


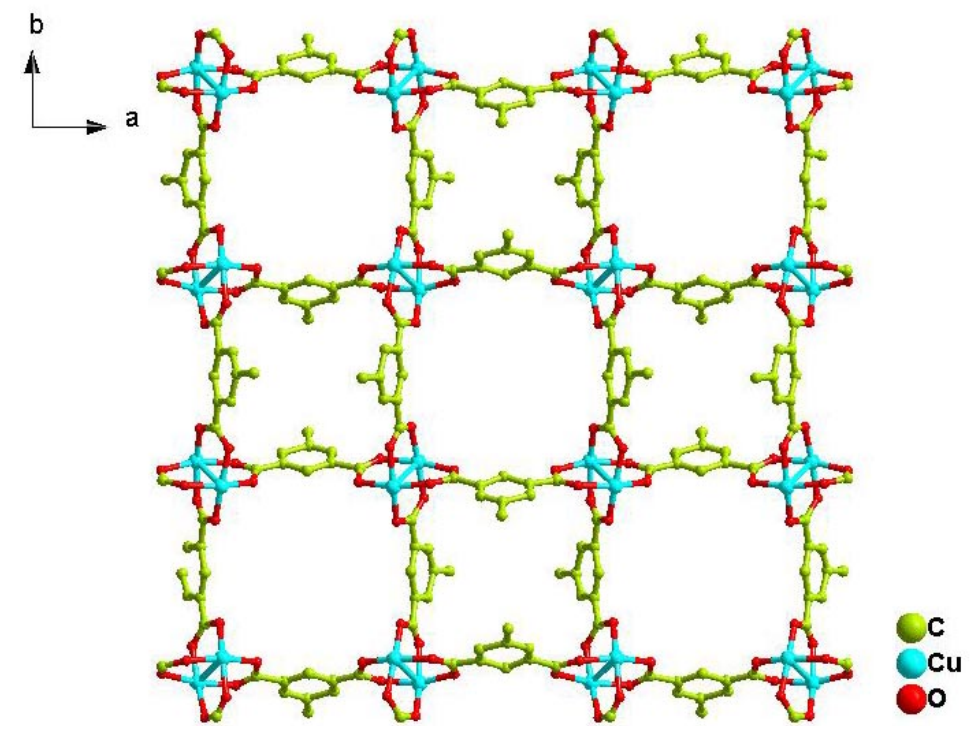

Figure S2 View of the 2D network with open channels of 1 with $\mathrm{H}$ atoms and water molecules omitted for clarity. 


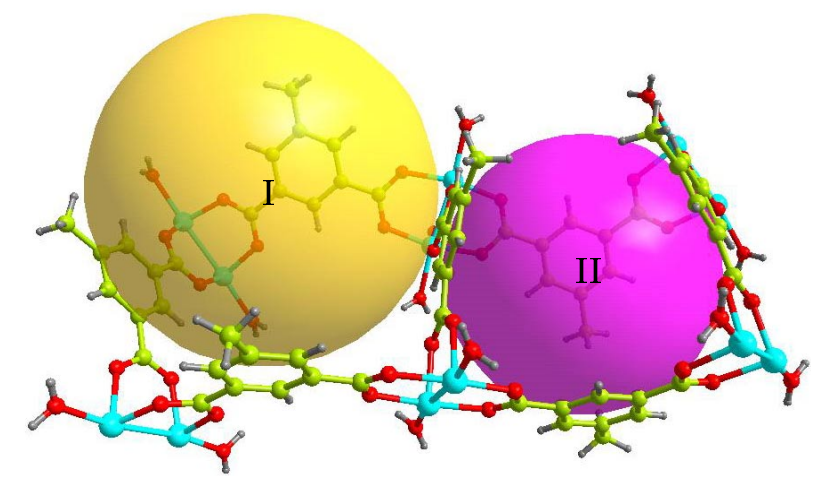

Figure S3 View of two kinds of calix[4]arene-liked grids, where the four aromatic rings of type I adopt a uniform cis- mode while the ones of type II adopt cis- and trans-alternative modes. 


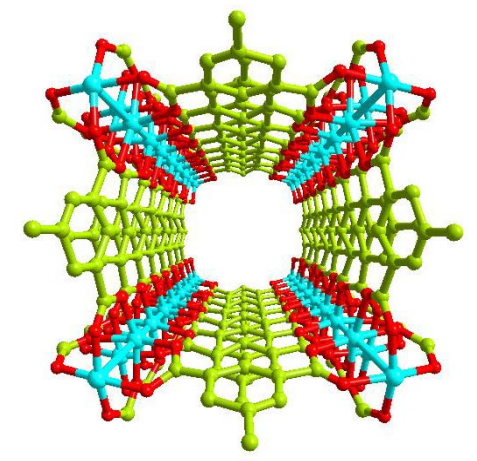

(a)

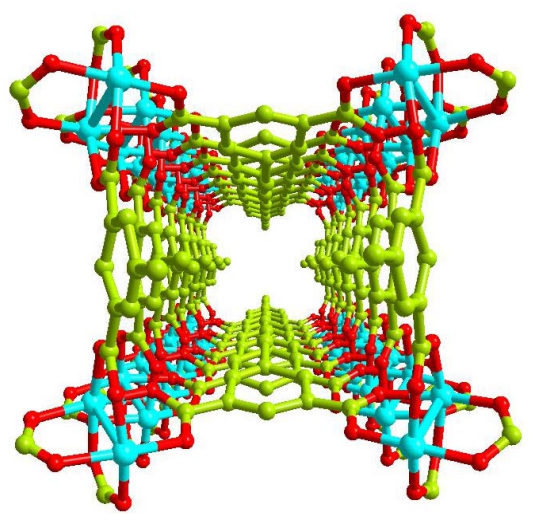

(b)

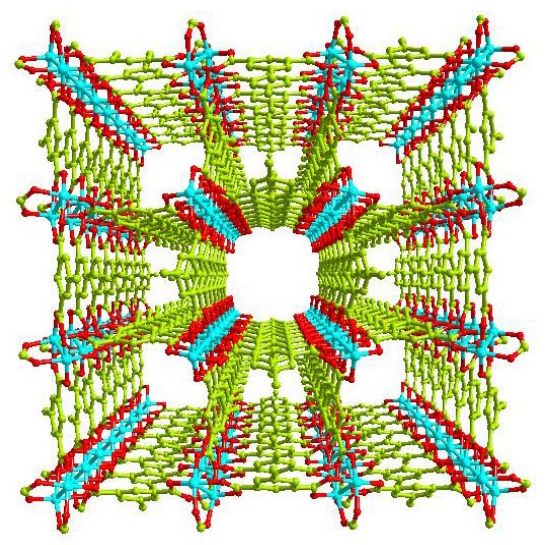

(c)

Figure S4 Two types of open channels of $\mathbf{1}$. 


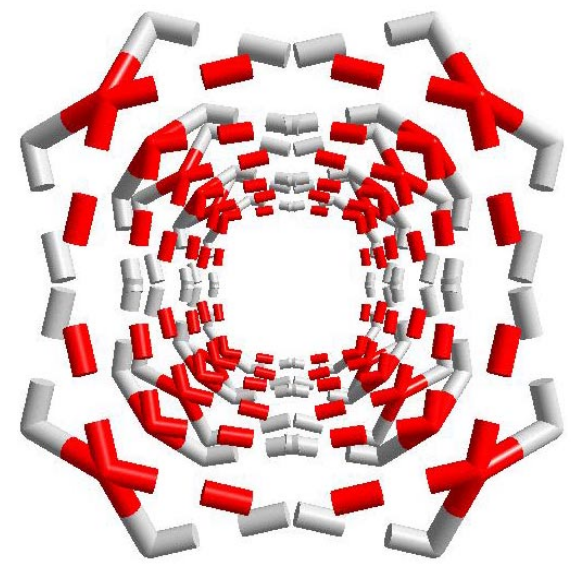

Figure S5 Two kinds of cyclic water tetramers arranged into 1D tube. 


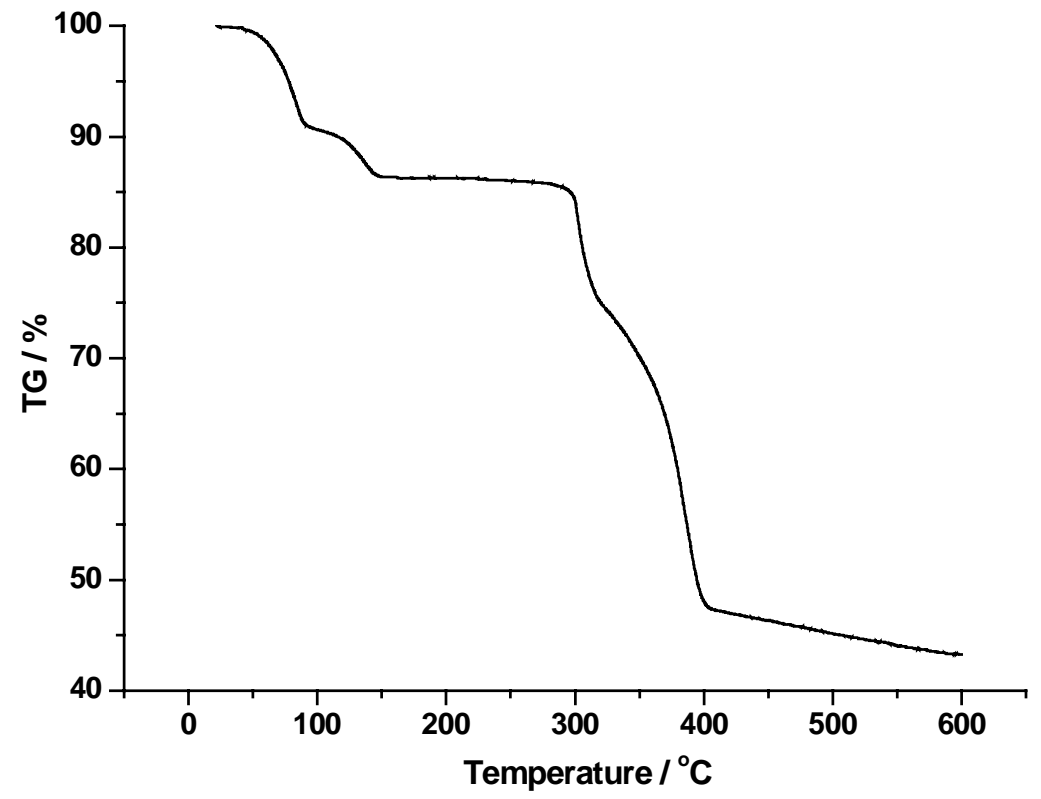

Figure S6 The TG pattern of $\mathbf{1}$. 


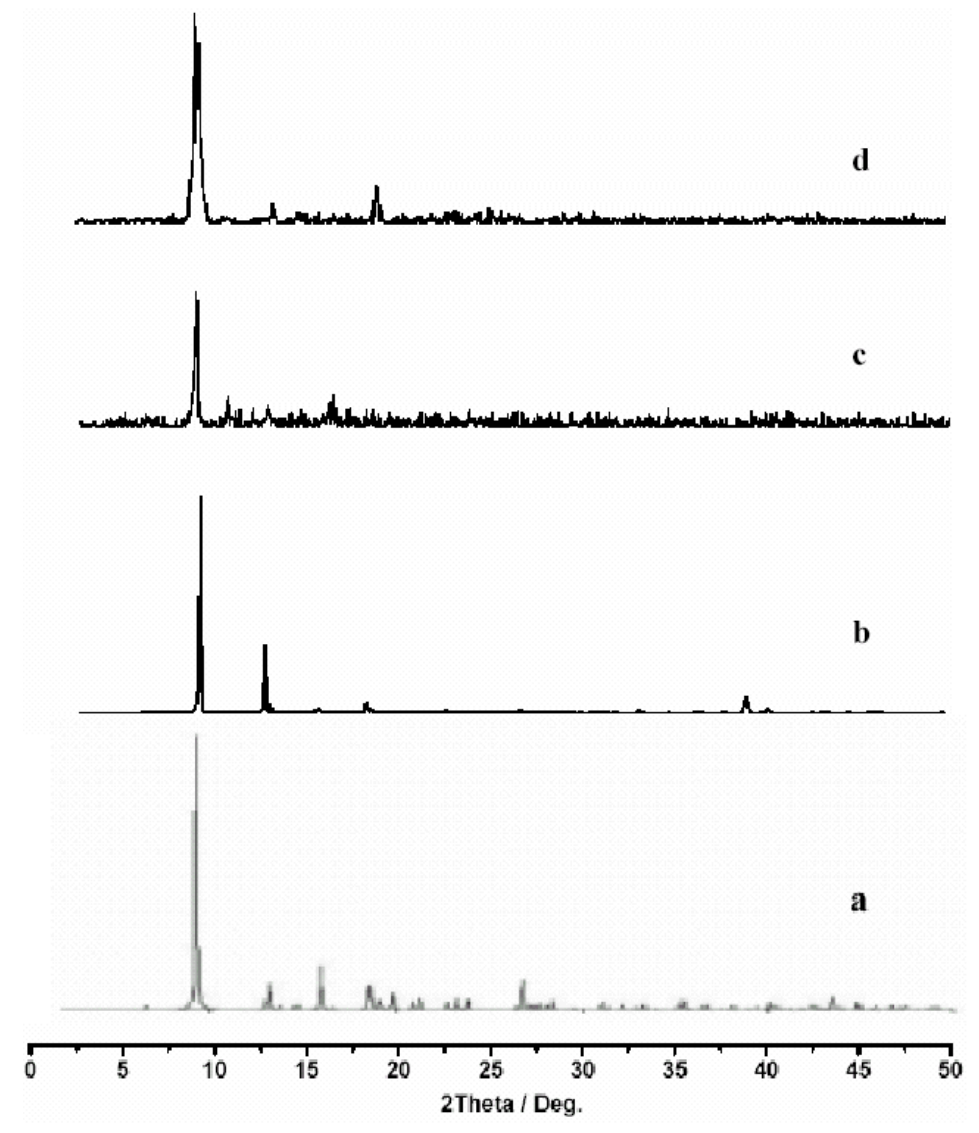

Figure S7 PXRD patterns for 1: (a) simulated from crystal data and (b) before removal of guest solvent molecules, (c) after removal of guest solvent molecules, (d) after catalytic reaction. 


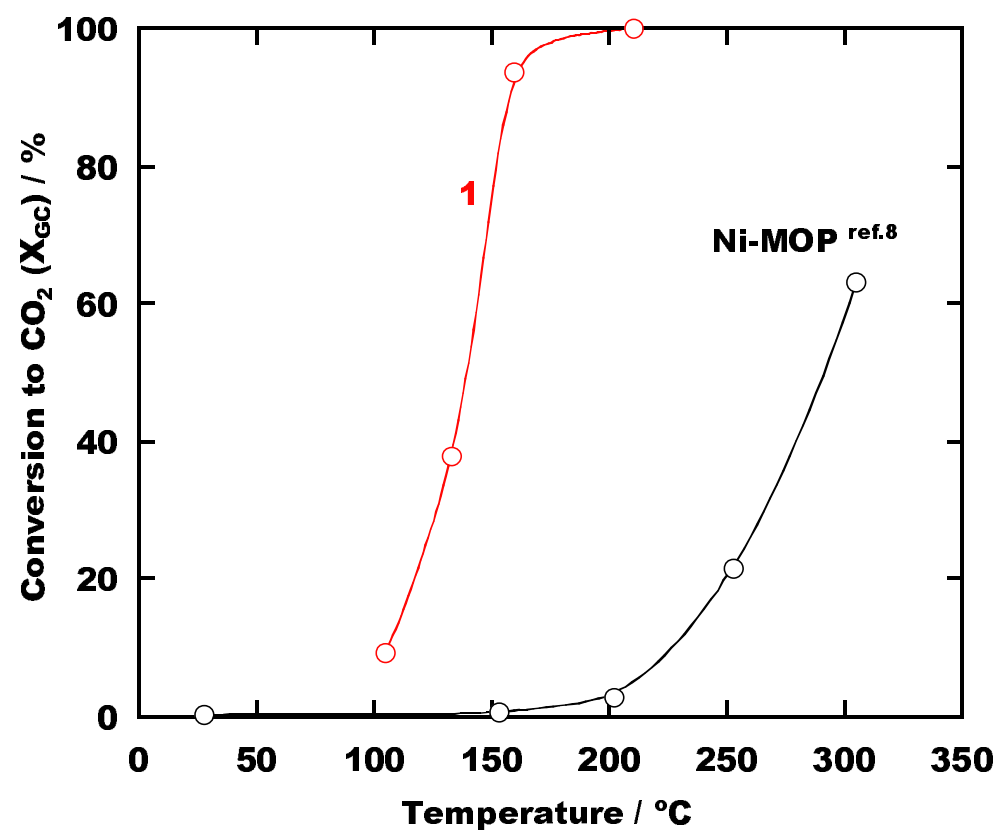

Figure S8 CO oxidation over 1 (activated at $250^{\circ} \mathrm{C}$ ) and the Ni-containing MOP measured on a flowing $\mathrm{CO}(1 \%)+\mathrm{O}(20 \%)+\mathrm{He}$ (balance) gas mixture $\left(\mathrm{SV}=20000 \mathrm{mLh}^{-1} \mathrm{~g}(\text { cat. })^{-1}\right)$. 


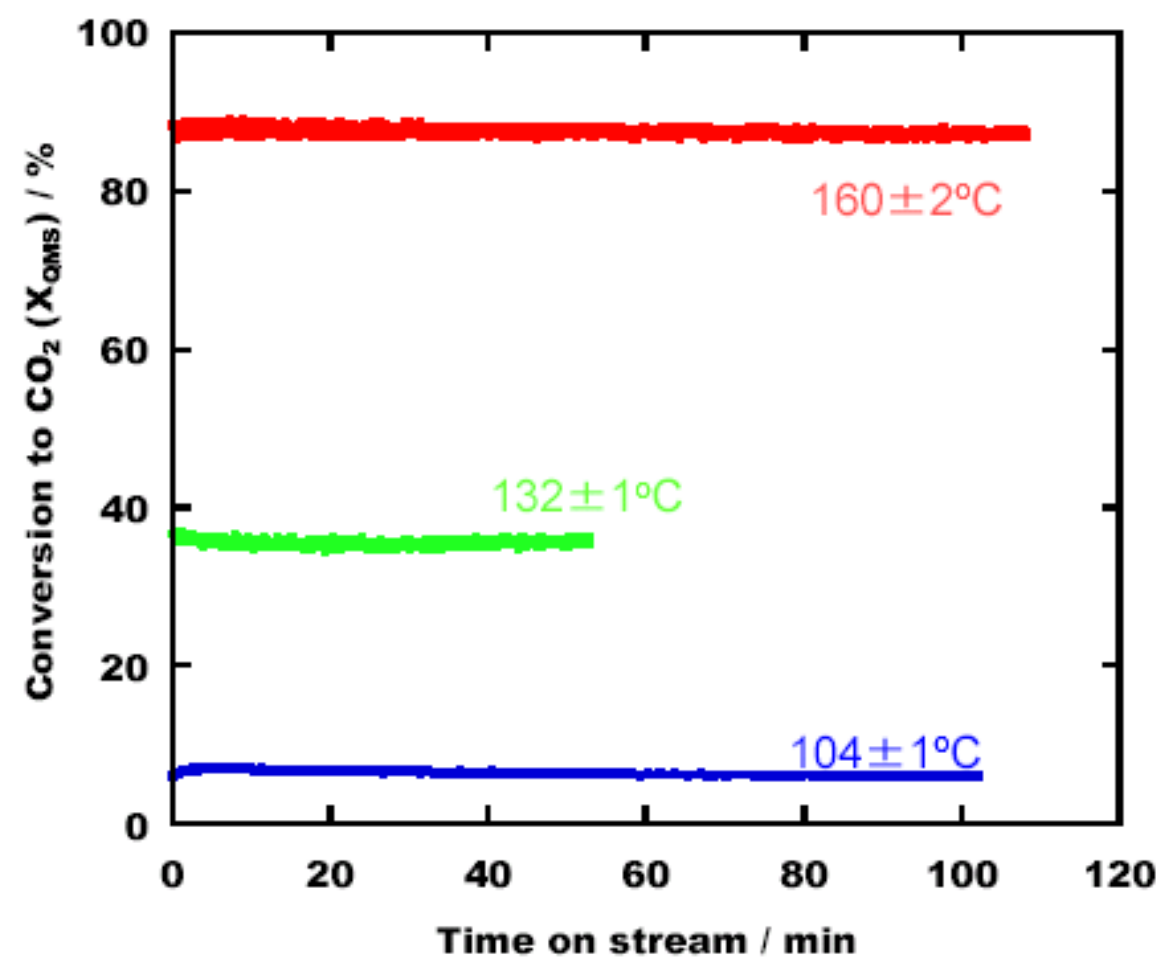

Figure S9 Catalytic activity of $\mathbf{1}$ in CO oxidation at 104,132 , and $160^{\circ} \mathrm{C}$, measured on a flowing CO $(1 \%)+\mathrm{O}(20 \%)+\mathrm{He}$ (balance) gas mixture $\left(\mathrm{SV}=20000 \mathrm{mLh}^{-1} \mathrm{~g}(\text { cat. })^{-1}\right)$. 


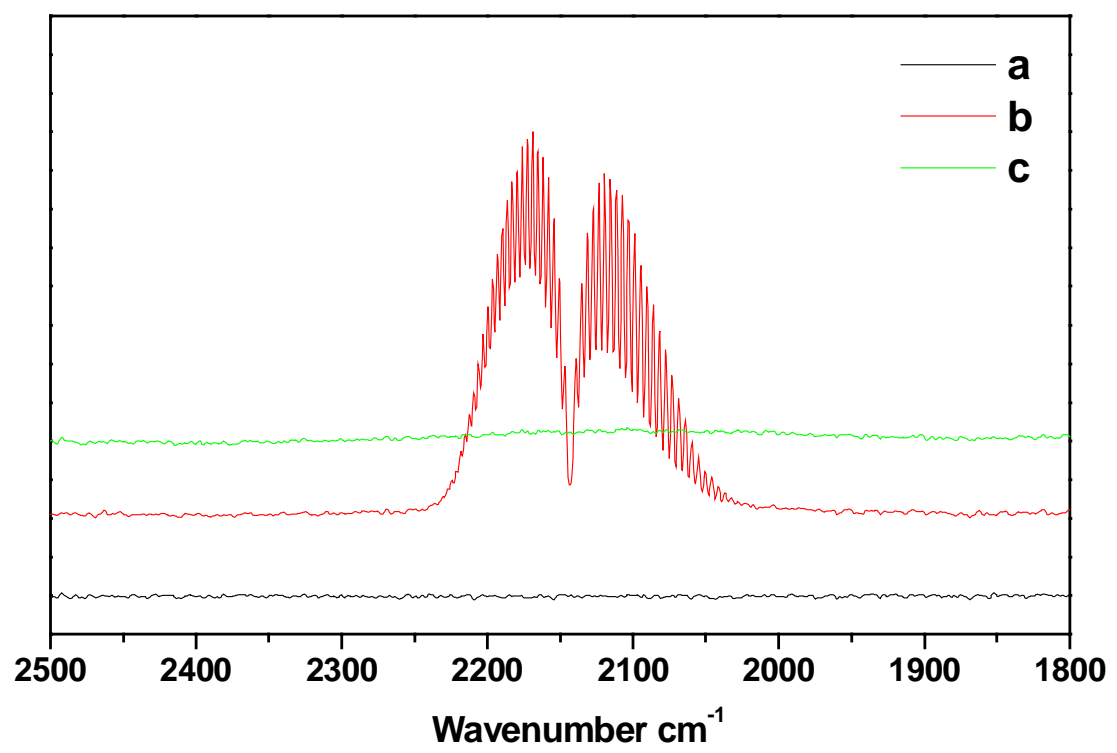

Figure S10 FTIR spectra of non-dehydrated 1 using the original sample as background: (a) as made, (b) under $\mathrm{CO}$ atmosphere, and (c) removal of the gas-phase $\mathrm{CO}$ using flowing Ar gas. 


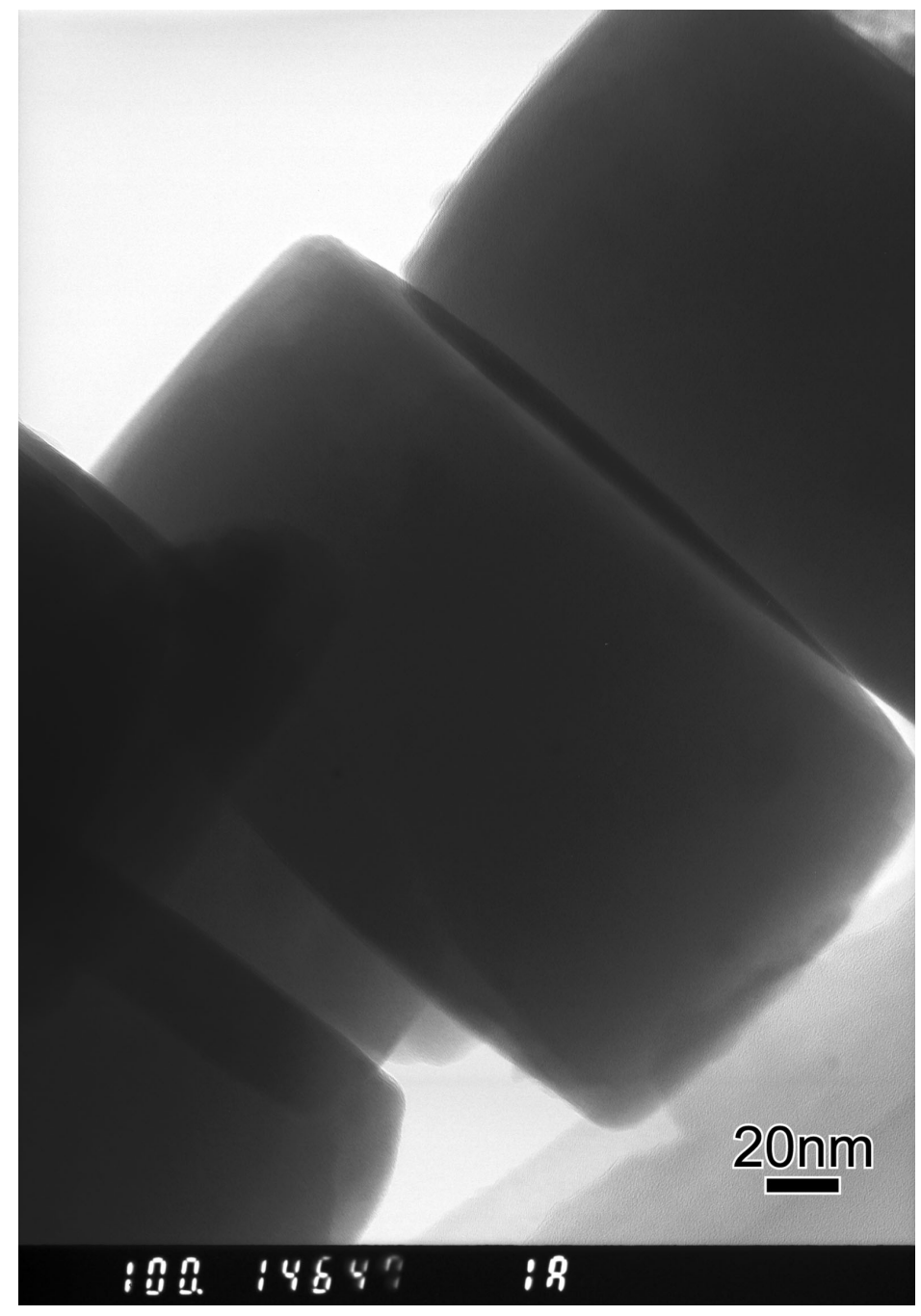

Figure S11 TEM micrograph of the materials of $\mathbf{1}$ after catalytic reaction. 